\title{
Pelesapan Preposisi dalam Gramatika Bahasa Indonesia $^{\mathbf{i}}$
}

\author{
F.X. Sawardi \\ FIB Universitas Sebelas Maret \\ sawardi2012@gmail.com
}

Diterima 14 Januari 2018/Disetujui 27 Maret 2018

\begin{abstract}
Abtract
This paper is based on the use of effective sentence-making rules in Indonesian language teaching which reads: subject and object should not be given a preposition. Sentences whose subject is preceded by a preposition are deemed ineffective / ungrammatical. Onthe other hand, the preposition is obligatory to express the role of locative, instrument, comitative, etc.. Under certain conditions the preposition is optional. For example, in the sentence Anjing itu dipukul (oleh) Ali. The problem are: (i) what is the preposition function in Indonesian grammar? (ii) at what position can the preposition be deleted? (iii) why are these prepositions be deleted? To answer the problem, the clause will be analyzed from the predicate and argument base. Arguments are distinguished from nonargument. Prepositions in the Indonesian language are used to distinguish arguments and non arguments, and determine the role of semantic constituent clauses. Prepositions may be fixed in (i) positions behind the direct verb, and (ii) the semantic role is obvious. The reason for this clear semantic role that makes the preposition can be wiped out.
\end{abstract}

Key word: deletion, preposition, bahasa Indonesia

\section{Pendahuluan}

Analisis kalimat (klausa verbal) berdasarkan predikat dan argumen telah digunakan oleh berbagai model tata bahasa, seperti model Tata Bahasa Relasional (Perlmutter dan Postal, 1983; Blake, 1990), Tata bahasa Leksikal Fungsional (Bresnan, 2016; Arka, 2002), dan Basic Linguistic Theory (Dixon, 2010a, 2010b, 2012; Artawa, 1997, Djunaidi, 2000, Jufrizal, 2006). Pada bahasa yang menggunakan kasus morfologis, perbedaan status argumen dinyatakan dalam perbedaan kasus. Sebaliknya, pada bahasa yang tidak menggunakan kasus morfologis, perbedaan status argumen dinyatakan dengan preposisi. Argumen inti tidak diberi pemarkah dengan preposisi, sedang bukan argumen inti dimarkahi dengan preposisi. Jenis preposisi tertentu memarkahi peran semantis argumen tertentu. Preposisi di, ke, dari memarkahi peran lokatif, dan dengan memarkahi peran instrument, bagi memarkahi peran beneficiary.

Peran preposisi kelihatan penting misalnya dalam rumusan sintaksis bahasa Indonesia disebutkan bahwa subjek dan objek gramatikal tidak boleh didahului dengan preposisi. Kalimat-kalimat yang subjeknya didahului dengan presposisi dinyatakan tidak baku/tidak gramatikal/tidak efektif. Salah satu contoh kalimat yang dinyatakan tidak baku adalah (1a) dan yang baku (1b) berikut.

(1) a. Dari peristiwa itu perlu mendapat perhatian dari perbagai pihak sehingga pada masa yang akan datang tidak seorangpun menuntut ganti rugi. 
b. Peristiwa itu mendapat perhatian berbagai pihak agar pada masa yang akan datang tidak ada seorangpun menuntut ganti rugi. (Sugono, 2011: 89)

Kalimat yang objeknya didahului dengan preposisi juga dinyatakan sebagai kalimat yang tidak baku/tidak gramatikal/tidak efektif. Kalimat (2a) berikut dianggap tidak baku, dan kalimat (2b) dianggap baku.

(2) a. Hari ini, kita tidak bicarakan tentang soal harga, melainkan tentang mutu barang itu.

b. Hari ini kita tidak membicarakan soal harga, tetapi soal mutu barang.

Di pihak lain Verhaar (1981: 78) menyatakan "bahasa Indonesia memungkinkan penafsiran fungsional "obyek berkata depan" menjadi "subyek berkata depan" dalam kalimat-kalimat tertentu. Dicontohkan oleh Verhaar kalimat yang menggunakan "obyek berkata depan" dan "subyek berkata depan" seperti berikut.

(3) a. Mengenai masalah ini akan kami uraikan nanti.

b. Kami akan menguraikan mengenai masaalah itu nanti.

Walaupun kalimat dengan objek dan subjek berpreposisi dinyatakan tidak baku, Muslim (2016) mengamati kalimat dengan subjek dan objek berkata depan itu digunakan oleh penutur bahasa Indonesia. Muslim (2016) menyebut bahwa subjek dan objek yang tidak menggunakan preposisi sebagai subjek objek yang kanonis, sedang subjek dan objek yang menggunakan preposisi sebagai subjek dan objek nonkanonis.Secara semantis dan pragmatis, subjek dan objek kanonis memiliki fungsi tersendiri.

Lepas dari kaitan subjek dan objek, ditemui prespoisi yang munculnya manasuka (opsional).Perhatikan contoh kalimat berikut.

(4) Anjing itu dipukul (oleh) Ali

(5) Dia masuk (ke) kamar jam tujuh.

(6) Setiap hari anak itu mandi (dengan) air hangat.

(7) Ia membelikan sepatu (untuk) Ali.

Presposisi-preposisi pada kalimat (4)-(7) boleh tidak digunakan diberi tanda kurung.

Pembicaraan kalimat (1) sampai dengan (7) semua berkaitan dengan preposisi. Kehadiran dan ketidakhadiran preposisi pada kalimat (1) dan (2) penting karena menjadi penentuan baku/tidak baku dalam kalimat. Pada kalimat (3) kehadiran preposisi pada subjek dan objek diakomodasi boleh digunakan. Pada kalimat (4)-(7) kehadiran atau ketidakhadiran preposisi tidak menentukan apa-apa.

Problem yang muncul adalah (i) apa sesungguhnya fungsi preposisi dalam gramatika bahasa Indonesia? (ii) pada posisi seperti apa preposisi dapat dilesapkan? (iii) mengapa presposisi-preposisi itu dapat dilesapkan?

\section{Kajian Pustaka}

Ada tiga hal yang berkaitan dengan kajian yang perlu disebutkan. Pertama berkaitan dengan preposisi, berkaitan dengan subjek dan objek, dan tiga tentang subjek dan objek nonkanonis. 
Pertama, berkaitan dengan penelitian preposisi dalam bahasa Indonesia, penelitian Ramlan (1980) yang dibukukan menjadi Kata depan atau Preposisi dalam Bahasa Indonesia merupakan hasil penelitian yang sudah lama ada. Penelitian ini mendokumentasikan semua preposisi yang ada dalam bahasa Indonesia dan penggunaannya. Penggunaan preposisi ini dirumuskan secara informal berdasarkan makna semantisnya.

Kedua, sudah lama diajarkan dalam buku-buku pengajaran bahasa, sintaksis bahasa Indonesia, bahwa subjek dan objek tidak boleh diberi preposisi (lihat misalnya Arifin, 1991, Sugono, 2011). Subjek dan objek tidak boleh diberi preposisi karena tidak efektif. Kalimat Kepada yang bersangkutan dimohon berdiri, misalnya, menurut tata bahasa, preposisi kepada harus dihilangkan. Kehadiran peposisi kepada dianggap membuat tidak efektif karena preposisi kepada umum digunakan untuk memarkahi beneficiary, tetapi pada kalimat tersebut merupakan objek yang sudah menjadi subjek.

Verhaar (1981: 78) adalah orang pertama yang menyebutkan ada subjek berkata depan dan objek berkata depan (dalam paper ini disebut subjek berpeposisi, dan objek berpreposisi) dalam bahasa Indonesia. Muslim (2016) menyebut sebagai subjek dan objek nonkanonis.

Ketiga, Muslim (2016) menyebutkan bahwa subjek dan objek nonkanonis dalam bahasa Indonesia memiliki fungsi tersendiri. Tiga hal penting yang dibahas oleh beliau. Pertama, berkaitan dengan konstruksi, kedua berkaitan dengan perilaku sintaksis, dan ketiga berkaian dengan motivasi penggunaan subjek-objek nonkanonis. Konstruksi subjek dan objek nonkanonis berkaitan dengan jenis verba. Jenis verba yang menggunakan subjek dan objek nonkanonis umumnya terjadi pada: (i) verba jenis komunikasi (seperti membicarakan, membahas, mendiskusikan); (ii) verba persepsi (seperti memikirkan, merenungkan, mengetahui); (iii) verba direktif (seperti mempersilakan, menghimbau, meminta); (iv) verba keberadaan (seperti memiliki, mempunyai, mengandung); dan adjektiva (seperti mudah). Berkaitan dengan perilaku sintaksis, subjek-objek nonkanonis secara sintaksis memiliki perilaku yang sama dengan subjek dan objek kanonis dalam hal pemasifan dan penggantian. Berkaitan dengan motivasi, ada tiga faktor yang menyebabkan adanya konstruksi nonkanonis. Faktor-faktor itu adalah kontaminasi, pengurangan derajat ketransitifan, dan pemudahan pemahaman. Berkaitan dengan perubahan, konstruksi nonkanonis sebenarnya sudah ada sejak sebelum abad XX seperti terlihat pada Malay Concordance Project (http://mcp.anu.edu.au) (Muslim, 2016: 525).

\section{Metodologi}

Artikel ini merupakan hasil penelitian terhadap fenomena kebahasaan yang berupa pelesapan preposisi pada klausa bahasa Indonesia. Data penelitian ini berupa kalimat-kalimat yang muncul (sebagai problem) dalam pengajaran sintaksis, pengajaran bahasa Indonesia, ditambah dengan kalimat dalam pengamatan penulis yang di dalamnya terdapat bentuk-bentuk preposisi yang mendahului subjek dan objek. 
Objek penelitian adalah pelelsapan preposisi pada klausa. Klausa dianalisis atas predikat dan argumen. Argumen dikelompokan dalam argumen inti (subjek dan objek) dan unsur yang lain (oblik dan adjunct) yang umumnya dimarkahi dengan preposisi. Pada berbagai jenis dan posisi, preposisi dilesapkan dan dicek keberterimaaannya. Preposisi yang dilesapkan dan kalimatnya tetap gramatikal dicari sebabnya: apakah karena posisi tempatnya, apakah karena perannya, atau faktor pragmatic. Faktor posisinya diuji dengan teknik penyisipan dengan unsur lain dan mutasi ke tempat lain. Pelesapan preposisi hanya dimungkinkan pada posisi tertentu atau semua posisi. Berkaitan dengan peran, diuji dengan penggantian peran-peran lain apakah dapat preposisi tetap dapat dilesapkan. Berkaitan dengan faktor pragmatik, diganti dengan peran konteks lain, apakah pelesapan preposisi tetap dapat diterima.

Hasil analisis tersebut dirumuskan dengan kalimat-kalimat biasa (metode informal Sudaryanto, 1990) tanpa disertai dengan rumusan matematik, atau simbol-simbol tertentu. Karena itu, rumusan hasil analisis melulu dirumuskan dengan kalimat.

\section{Hasil dan Pembahasan}

Secara umum diketahui bahasa Indonesia memiliki urutan struktur kalimat SPO (subjek-predikat-objek). Urutan tersebut adalah urutan yang ketat (Sudaryanto, 1983) sekaligus sebagai pemarkah konstituen gramatikal bahasa. Dalam paper ini, klausa dianalisis atas predikat dan argumen (Perlmutter dan Postal, 1983, Blake, 1990, Bresnan, 2016, Arka, 2002, Bresnan, 2016; Arka, 2002; Dixon, 2010a, 2010b, 2012; Artawa, 1997, Djunaidi, 2000, Jufrizal, 2006). Seperti dalam teori sintaksis pada umumnya, klausa yang dianalisis terutama adalah klausa verbal. Bahasa Indonesia memperlakukan verba dan adjektiva sama dalam pengertian dapat menduduki predikat sehingga istilah verbal dalam hal ini juga mencakup adjektiva. Kedua kelompok kata itu diberi istilah kata verbal oleh Ramlan (1986). Kata sifat dapat menduduki fungsi predikat seperti halnya verba tanpa tambahan kopula.

Analisis klausa yang digunakan adalah predikat dan argumen. Predikat biasanya verba, dan argumen adalah nomina/ frase nomina (Kroeger, 2006). Argumen adalah partisipan yang kehadirannya diisyaratkan oleh verba. Unsur lain yang sama sekali tidak diisyaratkan oleh verba disebut adjuncts (lihat misalnya Arka, 2017). Untuk jelasnya perhatikan kalimat di bawah ini.

(8) a. Ali memukul anjing di atas kandang dengan koran.

Ada satu predikat, yakni kata memukul, dan empat nomina yakni Ali, anjing, kebun, dan koran. Ali merupakan subjek kalimat dan ajing merupakan objek kalimat. Kehadiran Ali dan anjing diisyaratkan oleh verba memukul. Kata memukul mengisyaratkan adanya orang yang memukul dan sesuatu yang dipukul. Kata memukul tidak mengisyaratkan tempat, dan alat tertentu. Karena itu, selain Ali dan anjing pada kalimat (8a) bukan argumen/ (atau)adjunct. Seperti terlihat pada kalimat (8a) bahwa nomina selain, Ali dan anjing diberi preposisi. Di depan kata kandang ada preposisi di atas, dan di depan kata koran ada preposisi dengan. 
Dalam hal ini preposisi dipandang sebagai alat gramatikal untuk (i) membedakan argumen (Ali dan anjing) dan bukan argumen (kandang, koran), (ii) menyatakan peran nomina. Dengan preposisi di atas nomina kandang menjadi lokatif, dan dengan preposisi dengan nomina koran menjadi instrumental. Bila preposisi itu ditukar tempatnya, di atas ditukar dengan dengan, peran-peran itu juga menjadi terbalik. Perhatikan kalimat (8b) berikut.

(8) b. Ali memukul anjing di atas koran dengan kandang.

Pada kalimat (8b), koran tidak lagi instrumental tetapi menjadi lokatif, sebaliknya kandang tidak lagi berperan sebagai lokatif tetapi sebagi instrumental. Secara fungsional Ali dan anjing tetap sebagai subjek dan objek; dan Koran dan kandang tetap sebagai adjunct. Di antara argumen (subjek, dan objek) dengan adjunt ada satu fungsi lagi yang disebut oblik (oblique). Diisyaratkan oleh verba tetapi ditandai dengan preposisi. Misalnya kata meja pada kalimat (9) berikut.

(9) Ali meletakkan buku di atas meja.

Ada tiga nomina pada kalimat (9) yaitu, Ali, buku, dan meja. Ketiga nomina tersebut kehadirannya diisyaratkan oleh verba meletakkan. Ali sebagai subjek, buku sebagai objek tidak ditandai dengan preposisi sedang meja ditandai dengan preposisi di atas. Perbedaan nomina berpreposisi di atas meja pada kalimat (9), dengan nomina berpreposisi di atas kandang, dengan koran pada kalimat (8a), di atas koran, dengan kandang pada kalimat (8b) adalah kehadiaran nomina berpreposisi, di atas meja, pada kalimat (9) diisyaratkan oleh predikat verba meletakkan, dan nomina berpreposisi, di atas kandang dan dengan koran koran pada kalimat (8a) dan nomina berpreposisi, di atas koran, dan dengan kandang pada kalimat (8b) tidak.diisyaratkan oleh predikat memukul. Akibatnya, bila nomina berpreposisi pada kalimat (8a) dan (8b) dilesapkan, klausa tetap dianggap utuh, sebaliknya bila nomina berpeposisi pada kalimat (9) dilesapkan, klausa dianggap tidak utuh lagi/(atau)ada yang kurang. Dengan demikian ada istilah argumen inti (core/ term) (subjek, dan objek), bukan argumen (adjunct), di antara itu ada oblik (oblique). Oblik termasuk argumen atau bukan argumen menjadi issu yang menarik dalam teori linguistik sehingga ada satu jurnal yang dalam satu edisi mengangkat issu tersebut (lihat Linguistic Discovery 12.2 http://journals.dartmouth.edu/cgi-bin/WebObjects/Journals.woa/xmlpage/1/issue).

Di samping itu, batas oblik dengan argumen juga merupakan hal yang tidak tegas (clear cut). Batas kedua jenis argument tersebut lebih merupakan suatu continuum (Arka, 2017), tetapi Kroeger (2005: 62) memasukkan oblik sebagai argumen dan membuat diagram seperti berikut. 
(10) a Clausal Dependent

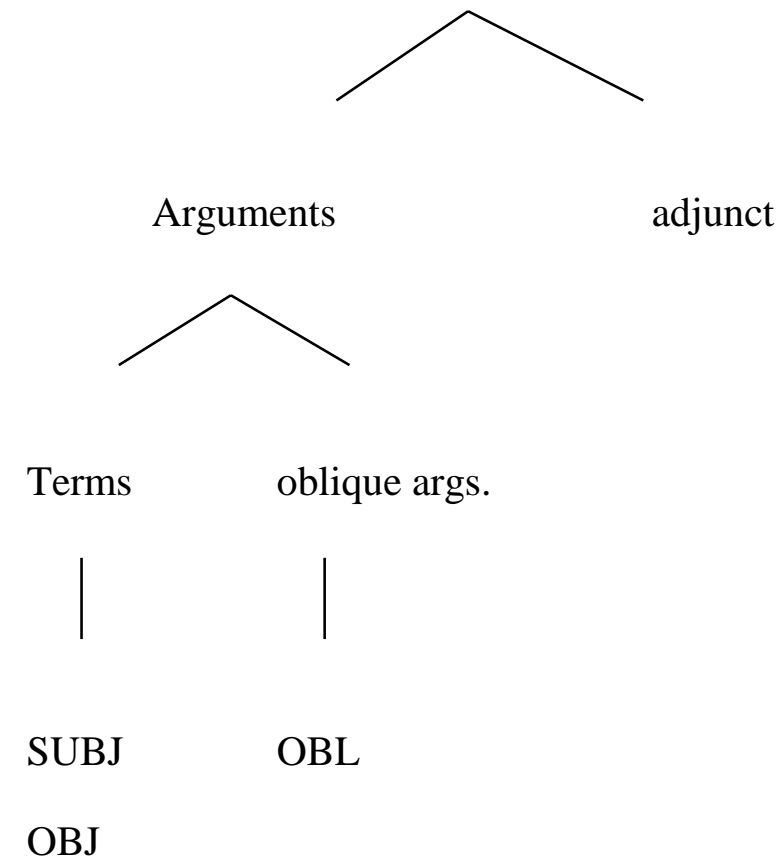

OBJ2

Dalam literatur, fungsi-fungsi itu dibuat hierarkhi menjadi (10b) berikut.

(10) b. SUBJ $>\mathrm{OBJ}>\mathrm{OBJ}_{\Theta}>\mathrm{OBL}>\mathrm{ADJ}$

Subjek menjadi fungsi paling tinggi diikuti fungsi-fungsi yang lain. Herarkhi seperti itu banyak digunakan untuk menerangkan berbagai fenomena kebahasan, seperti pengikatan, perelatifan.

Berkaitan dengan fungsi preposisi dalam gramatika bahasa Indonesia, preposisi berfungsi memarkahi argumen bukan inti. Selain subjek dan objek nomina diberi pemarkah preposisi. Seperti telah dijelaskan pada pengantar, adanya subjek berpreposisi dan objek berpreposisi dipermasalahkan dalam sintaksis bahasa Indonesia. Di satu sisi, kehadiran preposisi pada subjek dan objek dianggap membuat kalimat tidak efektif/ tidak gramatikal. Hanya pada verbaverba tertentu subjek dan objek berpreposisi diperbolehkan (Muslim, 2016). Subjek dan objek merupakan argumen inti yang memiliki kedudukan tinggi dalam peringkat (10b). Sebaliknya, kehadiran preposisi pada fungsi-fungsi di bawah oblik dan adjunct tidak dipermasalahkan bahkan wajib hadir.

Pada kalimat (8a), (8b), dan (9), kehadiran preposisi sebagai pemarkah konstituen yang bukan argumen. Argumen tidak inti (subjek dan objek) tidak dimarkahi dengan preposisi sedang konstituen yang bukan argumen inti dimarkahi dengan preposisi. Problemnya adalah bagaimana menjelaskan opsionalitas preposisi pada kalimat (4), (5), (6), dan (7). Penggunan preposisi oleh, ke, dengan, 
untuk yang bersifat opsional. Kehadiran nomina tersebut ada yang diisyaratkan oleh verba tetapi kehadiran preposisi dapat dilesapkan. Kedekatan letak dengan verba menjadi salah satu faktor penentu pelesapan preposisi. Perhatikan kalimat (4) yang dihadirkan lagi menjadi kalimat (11) dengan berbagai perubahannya.

(11) a. Anjing itu dipukul (oleh) Ali.

b. Anjing itu dipukul (oleh) Ali dengan sapu.

c. Anjing itu dipukul dengan sapu oleh Ali.

d. * Anjing itu dipukul dengan sapu Ali.

e. Anjing itu dipukul sapu oleh Ali.

f. * Anjing itu dipukul sapu Ali.

g. *Anjing itu dipukul (oleh) Ali sapu

Pada kalimat (11a), preposisi oleh digunakan untuk memarkahi argumen Ali tidak lagi menjadi argumen inti seperti pada bentuk aktifnya, Ali memukul anjing dengan sapu. Anehnya, kehadiran preposisi oleh tidak lagi wajib hadir pada kalimat (4a). Bila argumen Ali tidak berada di belakang verba secara langsung, preposisi oleh wajib digunakan. Pelesapan preposisi oleh yang tidak berada di belakang verba langsung seperti kalimat (11d) tidak dimungkinkan.Demikian juga dengan preposisi dengan yang digunakan sebagai pemarkah instrumental.Bila nomina yang ditandai dengan preposisi dengan berada langsung di belakang verba dipukul, preposisi oleh dapat dilesapkan seperti terlihat pada kalimat (11e).Bila nomina sapu tidak berada langsung di belakang verba dipukul preposisi dengan wajib digunakan seperti pada kalimat (11b). Bila preposisi dengan pada kalimat (11b) dilesapkan, kalimat menjadi tidak gramatikal (lihat kalimat (11g)).Kedekatan letak dengan predikat verba menjadi penentu opsionalitas preposisi.

Ternyata tidak semua preposisi di belakang verba dapat dilesapkan seperti kasus kalimat (11). Hubungan asosiatif ternyata juga menentukan. Verba seperti masuk pada kalimat (5) sangat erat dengan lokatif dibandingkan dengan instrumen. Verba mandi pada kalimat (6) lebih erat dengan instrumen dibandingkan dengan lokasi. Kalimat (5) dan (6) dihadirkan lagi pada kalimat (12) dan (13) berikut.

(12) a. Dia masuk (ke) kamar jam tujuh.

b. Dia masuk (ke) kamar dengan kursi roda.

c. Dia masuk dengan kursi roda ke kamar.

d. *Dia masuk kursi roda ke kamar.

(13) a. Setiap hari anak itu mandi (dengan) air hangat.

b. Setiap hari anak itu mandi dengan sabun cair.

c. *Setiap hari anak itu mandi sabun cair.

Verba masuk pada kalimat (12) lebih erat dengan lokasi. Semua nomina yang berkonasi lokatif dapat mengikuti verba tersebut tanpa preposisi.Nomina yang tidak memiliki konotasi lokatif tidak diterima. Kalimat (12d) tidak diterima karena kursi roda tidak lebih berkonotasi sebagai instrument daripada lokatif (meskipun diterima juga kalimat Dia duduk di kursi roda). 
Verba membelikan memiliki argumen orang yang membeli, sesuatu yang dibeli, dan orang yang dibelikan. Yang menjadi masalah adalah dua nomina di belakang verba, yakni sesuatu yang dibeli, dan orang yang dibelikan. Dua konstituen itu dibedakan atas bernyawa dan tidak bernyawa.Yang bernyawa akan berperan sebagai benefaktif, dan yang tidak bernyawa sebagai theme atau pasien . Perhatikan kalimat di (14) berikut.

(14) a. Dia membelikan sepatu (untuk) Ali.

b. Dia membelikan Ali sepatu.

c. ?Dia membelikan perpustakaan buku.

d. ?Dia membelikan ayam harimau.

e. ?Dia membelikan harimau ayam.

Preposisi dapat dilesapkan pada kalimat (14a) karena hubungan asosiatifnya jelas.Kalimat (14c), (14d), (14e) hubungan asosiatifnya tidak jelas karena kedua nomina yang mengikuti verba tidak bernyawa/ keduanya bernyawa tetapi tidak ada penanda preposisi.

\section{Simpulan}

Simpulan yang dapat ditarik adalah (i) preposisi dalam bahasa Indonesia digunakan untuk: pertama, membedakan argumen dan bukan argumen; kedua, untuk memarkahi peran semantik dalam dalam struktur klausa; (ii) dalam kaitan fungsi gramatikal, prepsosisi digunakan pada fungsi-fungsi adjunct dan oblik; dan preposisi dapat dilesapkan pada pemarkah nomina yang letaknya dibelakang langsung verba dan memiliki asosiasi peran yang jelas dengan verbanya; (iii) karena hubungan asosiasi yang sudah jelas tersebut preposisi dapat dilesapkan.

\section{Daftar Pustaka}

Arifin, E. Z. \& Tasai, 1991.Cermat Berbahasa Indonesia untuk Perguruan Tinggi.Jakarta: Mediyatama Sarana Perkasa.

Arka, I W. 2002. "Tata Bahasa Leksikal-Fungsional: Beberapa Prinsip Dasar dan Tantangannya dalam Penerapannya pada Bahasa-Bahasa Nusantara" Makalah Pelbba XVI. Jakarta: Universitas Katolik Atma Jaya.

Arka, I.W.2017. "The Core-Oblique Distinction in Some Austronesian Languages of Indonesia and Beyond" dalam Linguistik Indonesia. Jakarta: Masyarakat Linguistik Indonesia.

Bresnan, Joan et.al..2016. Lexical Functional Syntax. Oxford: Blackwell Publisher.

Dixon, R.M.W..2010a. Basic Linguistic Theory Volume 1. Oxford: Oxford University Press. 
Dixon, R.M.W..2010b. Basic Linguistic Theory Volume 2. Oxford: Oxford University Press.

Dixon, R.M.W..2012. Basic Linguistic Theory Volume 3. Oxford: Oxford University Press.

Kroeger, P..2005. Analyzing Grammar: An Introduction. Cambridge: Cambridge University Press.

Muslim, M. Umar. 2016. "Subjek Objek Nonkanonis dalam Bahasa Indonesia", Proceeding Konferensi Internasional Masyarakat Linguistik Indonesia, Denpasar: Universitas Udayana.

Ramlan, M. 1980. Kata Depan atau Preposisi dalam Bahasa Indonesia. Yogyakarta: UP Karyono.

Ramlan, M. 1986. Tata Bahasa Indonesia Penggolongan Kata. Yogyakarta: Andi Offset.

Sudaryanto. 1983. Predikat Objek dalam bahasa Indonesia: Keselarasan Polaurutan. Jakarta: Djambatan.

Sudaryanto. 1990. Metode Linguistik Bagian Pertama: ke arah Memahami Metode Linguistik. Yogyakarta: Gadjah Mada University Press.

Sugono, D. (ed).2011. Buku Praktis Bahasa Indonesia. Jakarta: Badan Pengembangan dan Pembinaan Bahasa Kementrian Pendidikan dan Kebudayaan.

Verhaar, J.W.M. . 1981. Pengantar Lingguistik Umum.Yogyakarta: Gadjah Mada University Press.

\footnotetext{
${ }^{\mathrm{i}}$ Versi awal tulisan disampaikan pada Seminar Internasional Pertemuan Ilmiah Bahasa dan Sastra Indonesia (PIBSI) XXXVIII 2016 di Universitas Bangun Nusantara Sukoharjo, terima kasih kepada para peserta seminar yang telah memberi masukan pada paper ini. Terima kasih juga kami sampaikan kepada mitra bestari Jurnal Semiotika yang telah memberi masukan yang sangat berharga untuk penyempurnaan tulisan ini.
} 